\title{
GAMBARAN PERILAKU MEROKOK PADA REMAJA LAKI-LAKI
}

\author{
1] Misbakhul Munir \\ Email Korespondensi : misbakhul munir@uinsby.ac.id \\ Universitas Islam Negeri Sunan Ampel Surabaya, Indonesia
}

\begin{abstract}
The prevalence of smoking behaviour in Indonesia shows improvement. Based on basic health Research (RISKESDAS) in 2010, the national prevalence of smokers was 34.7\%, while in 2013, the prevalence increased to $36.3 \%$. Males most perform smoking behaviour. It can harm the health of its smokers and can also damage the health of the surrounding environment. There are three phases of urgent clinics in tobacco addiction, namely: try, sometimes use and use every day. There are several factors of smoking behaviour for adolescents, such as psychological factors, biological factors and environmental factors. The purpose of this research is to know the factors affecting the behaviour of smoking in male adolescents. The method in this study used a type of descriptive research with the population of all male students in UIN Sunan Ampel Surabaya. The sampling technic used is a accidental sampling with several respondents amounting to 50 students. It gained a result that $46 \%$ began to smoke at the age of 17-19 while still in high school and belongs to the category of mild smokers. These smoking behaviours are influenced by family support, friend encouragement and ad influence.
\end{abstract}

\begin{abstract}
Abstrak
Prevalensi perilaku merokok di Indonesia menunjukkan peningkatan. Berdasarkan Riset Kesehatan Dasar (Riskesdas) pada tahun 2010, secara nasional prevalensi perokok yaitu 34,7\%, sedangkan pada tahun 2013, prevalensi meningkat menjadi 36,3\%. Perilaku merokok paling banyak dilakukan oleh laki-laki.Hal ini dapat merugikan kesehatan perokok sendiri dan juga dapat merugikan kesehatan lingkungan sekitarnya. Terdapat tiga fase klinik penting dalam kecanduan tembakau yaitu: mencoba, kadang-kadang menggunakan, dan menggunakan setiap hari. Terdapat beberapa faktor perilaku merokok bagi remaja, misalnya faktor psikologi, faktor biologi dan faktor lingkungan.Tujuan dari penelitian ini adalah untuk mengetahui faktor-faktor yang mempengaruhi perilaku merokok pada remaja laki-laki.Metode dalam penelitian ini menggunakan jenis penelitian deskriptif dengan populasi semua mahasiswa laki-laki di UIN Sunan Ampel Surabaya. Pengambilan sampel menggunakan teknik accidental sampling dengan jumlah responden sebesar 50 mahasiswa. Didapatkan hasil bahwa 46\% mulai merokok pada usia 17-19 tahun ketika masih SMA dan termasuk kategori perokok ringan. Perilaku merokok ini dipengaruhi oleh dukungan keluarga, dorongan teman dan pengaruh iklan.
\end{abstract}

\section{Kata Kunci: Perilaku Merokok; Prevalensi; Remaja}

\section{PENDAHULUAN}

Perilaku merokok merupakan perilaku yang berbahaya bagi kesehatan, namun masih banyak orang yang melakukan kegiatan merokok, bahkan seseorang mulai merokok dimulai sejak remaja. Aktivitas ini banyak dijumpai pada remaja laki-laki (1). Perilaku merokok adalah perilaku yang dinilai sangat merugikan bagi kesehatan dalam berbagai sudut pandang, baik bagi diri sendiri maupun orang lain di sekitarnya (2). Bahaya yang ditimbulkan akibat rokok sudah banyak diketahui oleh semua orang, tetapi hal ini tidak mengurangi dan hampir setiap saat dapat dijumpai banyaknya orang yang sedang merokok (3). Bahkan perilaku merokok sudah sangat dianggap suatu hal yang wajar untuk para remaja, khususnya remaja laki-laki (4). 
Pada tahun 2030 diperkirakan angka kematian akibat rokok di dunia akan mencapai 10 juta jiwa. Berdasarkan data tersebut, 70\% di antaranya adalah berasal dari negara berkembang. Prosentase kematian akibat rokok di negara berkembang adalah sebanyak 50\% (5).

WHO (World Health Organitations) menunjukkan bahwa Indonesia menduduki peringkat ketiga dunia setelah Cina (390 juta perokok) dan India (144 juta perokok). Berdasarkan Riset Kesehatan Dasar (RISKESDAS) pada tahun 2010, secara nasional prevalensi perokok yaitu $34,7 \%$ atau sebanyak 80 juta penduduk (6). Sedangkan pada tahun 2013, prevalensi meningkat menjadi 36,3\% (7).

Peningkatan konsumsi berdampak pada semakin tingginya penyakit yang diakibatkan oleh rokok dan bertambahnya angka kematian akibat rokok. Pada tahun 2013, rata-rata jumlah batang rokok yang dihisap adalah sekitar 12,3 batang per hari. Hampir 80\% perokok mulai merokok pada usia belum mencapai 19 tahun. Umumnya orang mulai merokok sejak muda dan keputusan konsumen untuk membeli rokok tidak didasarkan pada informasi yang cukup tentang risiko mengenai bahaya adiktif rokok, produk yang dibeli, efek ketagihan, dan dampak pembelian yang dibebankan pada orang lain. Prevalensi perilaku merokok pada laki-laki usia >15 tahun sebanyak $36,3 \%$ (angka ini cenderung terjadi peningkatan dibandingkan pada tahun 2007 yaitu sebesar 34,3\%). Hasil RISKESDAS pada tahun 2007, 2010, dan 2013 menunjukkan bahwa usia merokok pertama kali paling tinggi adalah pada kelompok usia 15-19 tahun (5).

Data WHO pada tahun 2011, menyebutkan bahwa perokok tidak saja dilakukan oleh pria, namun juga oleh wanita. Data global menyatakan bahwa $63 \%$ pria adalah perokok dan sisanya sebanyak 4,5\% adalah perokok wanita. Sedangkan statistik perokok dari kalangan remaja Indonesia, yaitu $24,1 \%$ remaja pria adalah perokok dan $4,0 \%$ remaja wanita adalah perokok (8).

Perilaku merokok dilihat dari berbagai sudut pandang sangat merugikan baik untuk diri sendiri maupun untuk orang lain. Pada saat merokok, seseorang menghisap kurang lebih 4000 bahan kimia yang berbahaya. Bahan berbahaya tersebut adalah nikotin, tar, karbon monoksida, serta bahan kimia beracun lainnya.Nikotin menyebabkan terjadinya ketergantungan atau adiksi. Tar bersifat karsogenik. Sedangkan karbon monoksida mempunyai afisitas yang sangat kuat terhadap hemoglobin sehingga kadar oksigen dalam darah menjadi berkurang (9).

Terdapat tiga fase klinik penting dalam kecanduan tembakau yaitu: mencoba, kadang-kadang menggunakan, dan menggunakan setiap hari. Seperti penggunaan zatzat (substances) lainnya, terdapat beberapa faktor bagi remaja sehingga mereka menjadi perokok, misalnya faktor psikologi, faktor biologi dan faktor lingkungan (10). Perilaku merokok yang dinilai merugikan telah bergeser menjadi perilaku yang menyenangkan dan menjadi aktifitas yang bersifat obsesif. Faktor terbesar dari kebiasaan merokok adalah faktor sosial atau lingkungan.Terkait hal itu, kita tentu telah mengetahui bahwa karakter seseorang banyak dibentuk oleh lingkungan sekitar, baik keluarga, tetangga, ataupun teman pergaulan (2).

Studi pendahuluan yang dilakukan kepada 20 mahasiswa Fakultas Psikologi dan Kesehatan UIN Sunan Ampel Surabaya dengan wawancara, didapatkan hasil 
bahwa 16 orang (80\%) diantaranya adalah perokok aktif. Mereka rata-rata merokok lebih dari 10 batang rokok dalam sehari (11). Perilaku merokok pada mahasiswa tersebut mayoritas dipengaruhi oleh faktor dukungan teman (5).

Berdasarkan temuan-temuan di atas maka maka perlu dilakukan penelitian lebih lanjut tentang perilaku merokok pada remaja. Penelitian ini dilakukan pada mahasiswa UIN Sunan Ampel Surabaya. Tujuan penelitian ini yaitu untuk mengetahui gambaran perilaku merokok pada mahasiswa laki-laki.

\section{METODOLOGI PENELITIAN}

Penelitian ini merupakan jenis penelitian deskriptif. Populasi pada penelitian ini adalah mahasiswa laki-laki UIN Sunan Ampel Surabaya dan menggunakan tehnik accidental sampling dengan kriteria inklusi mahasiswa yang merokok dan bersedia menjadi responden dalam penelitian, diperoleh 50 sampel. Proses pengumpulan data pada penelitian ini dengan menggunakan alat ukur kuesioner.

\section{HASIL PENELITIAN}

Distribusi frekuensi karakteristik responden tentang memulai perilaku merokok akan ditampilkan pada tabel 1

Tabel 1 Distribusi Frekuensi Memulai Perilaku Merokok pada 50 Responden

\begin{tabular}{cccc}
\hline Pendidikan & \multicolumn{1}{c}{ Usia } & Frekuensi & Presentase (\%) \\
\hline SD & 7-12 tahun & 4 & 8 \\
SMP & 13-16 tahun & 17 & 34 \\
SMA & 17-19 tahun & 23 & 46 \\
Kuliah & 20-24 tahun & 6 & 12 \\
\hline Total & & $\mathbf{5 0}$ & $\mathbf{1 0 0}$ \\
\hline
\end{tabular}

Pada tabel di atas dapat dilihat bahwa, perilaku merokok dimulai oleh remaja laki-laki paling banyak pada usia SMA (17-19 tahun) yaitu sebesar 46\%.

Distribusi frekuensi karakteristik responden tentang jumlah batang rokok yang dihabiskan dalam sehari akan ditampilkan pada tabel 2.

Tabel 2 Distribusi Frekuensi Jumlah Batang Rokok Habis dalam Sehari dari 50 Responden

\begin{tabular}{lll}
\hline $\begin{array}{l}\text { Jumlah Batang Rokok Habis } \\
\text { Sehari }\end{array}$ & Frekuensi & Prosentase (\%) \\
\hline 1-10 Batang & 32 & 64 \\
11-20 Batang & 13 & 26 \\
$>$ 20 Batang & 5 & 10 \\
\hline \multicolumn{1}{c}{ Total } & $\mathbf{5 0}$ & $\mathbf{1 0 0}$ \\
\hline
\end{tabular}


Berdasarkan tabel 2 di atas, menunjukkan bahwa jumlah batang yang dihisap setiap hari oleh sebagian besar responden yaitu 1-10 batang (64\%).

Distribusi frekuensi responden berdasarkan dorongan keluarga ditampilkan pada tabel 3.

Tabel 3 Distribusi Frekuensi 50 Responden Berdasarkan Dorongan Keluarga

\begin{tabular}{lll}
\hline Pengaruh Keluarga & Frekuensi & Prosentase (\%) \\
\hline Rendah & 0 & 0 \\
Sedang & 30 & 60 \\
Tinggi & 20 & 40 \\
\hline \multicolumn{1}{c}{$\quad$ Total } & $\mathbf{5 0}$ & $\mathbf{1 0 0}$ \\
\hline
\end{tabular}

Berdasarkan tabel 3 di atas, menunjukkan bahwa sebagian besar responden merokok karena adanya pengaruh dari keluarga pada tingkat sedang, yaitu sebanyak 30 responden $(60 \%)$. tabel 4

Distribusi frekuensi responden berdasarkan dorongan teman ditampilkan pada

Tabel 4 Distribusi Frekuensi 50 Responden Berdasarkan Dorongan Teman

\begin{tabular}{|c|c|c|}
\hline Dorongan Teman & Frekuensi & Prosentase (\%) \\
\hline Rendah & 9 & 18 \\
\hline Sedang & 30 & 60 \\
\hline Tinggi & 11 & 22 \\
\hline Total & 50 & 100 \\
\hline
\end{tabular}

Berdasarkan tabel 4 di atas, menunjukkan bahwa sebagian besar responden merokok karena adanya dorongan dari teman pada tingkat sedang, yaitu sebanyak 30 responden $(60 \%)$. tabel 5 .

Distribusi frekuensi responden berdasarkan dorongan iklan ditampilkan pada

Tabel 5 Distribusi Frekuensi 50 Responden Berdasarkan Dorongan Iklan

\begin{tabular}{lll}
\hline Dorongan Iklan & Frekuensi & Prosentase (\%) \\
\hline Rendah & 1 & 2 \\
Sedang & 15 & 30 \\
Tinggi & 34 & 68 \\
\hline Total & $\mathbf{5 0}$ & $\mathbf{1 0 0}$ \\
\hline
\end{tabular}

Berdasarkan tabel 5 di atas, menunjukkan bahwa sebagian besar responden merokok karena dorongan dari iklan yang tinggi, yaitu sebanyak 34 responden (68\%). 


\section{PEMBAHASAN}

Hasil penelitian ini menyebutkan bahwa mayoritas responden mulai merokok pada waktu SMA dan berusia 17-19 tahun (46\%). Usia ini termasuk dalam rentang remaja akhir. Pada masa ini, remaja biasanya mulai mencari jati diri dan menyesuaikan dengan lingkungan yang baru, salah satunya dengan Global Youth Tobacco Survey (GYTS) menunjukkan Indonesia sebagai negara dengan angka perokok remaja tertinggi di dunia pada tahun 2014 (12).

Hasil penelitian ini sejalan dengan penelitian yang dilakukan oleh Pertiwi, dkk pada tahun 2019. Dalam penelitian ini disebutkan bahwa responden mulai merokok pada usia 18-20 tahun pada jenjang pendidikan SMA sebesar 84\% (13). Data dari Susenas juga menyatakan pada tahun 1995 sampai tahun 2010, orang mulai merokok pada usis 15-19 tahun (14).

Mayoritas responden pada penelitian ini menghisap 1-10 batang rokok per hari dengan jumlah sebanyak 32 responden (64\%) sehingga perilaku merokok dikategorikan menjadi perokok ringan. Menurut WHO dikategorikan perokok ringan apabila menghisap 1-10 batang rokok per hari, perokok sedang apabila menghisap 1120 batang rokok per hari dan perokok berat apabila menghisap lebih dari 20 batang okok per hari. Hasil penelitian ini sejalan dengan penelitian dari Astuti pada tahun 2019 yang menyatakan bahwa 63,64\% dari respondennya merokok kurang dari 10 batang rokok per harinya (15).

Perilaku merokok juga dapat dipengaruhi oleh faktor ekstrinsik yang meliputi pengaruh keluarga dan lingkungan sekitar, pengaruh teman sebaya dan pengaruh iklan rokok (16). Penelitian ini menunjukkan perilaku merokok pada responden yang dipengaruhi oleh keluarga dan teman ada pada tingkat sedang. Sedangkan pengaruh paling tinggi disebabkan karena iklan.

Penelitian ini sesuai dengan penelitian dari Piyanto pada tahun 2016, bahwa perilaku merokok dipengeruhi oleh keluarga pada tingkat sedang. Menurut penelitian dari Aliyah pada tahun 2011 disebutkan juga bahwa apabila orang tua atau anggota keluarga lainnya merokok maka akan mendorong untuk menjadi perokok pemula di usia mahasiswa dengan kemungkinan merokok 1,5 kali pada anak lelaki (Al-Zalabani \& Kasim, 2015). Selain itu, secara psikologis akan memberikan toleransi asap rokok di rumah sehingga akan menanamkan nilai bahwa merokok diperbolehkan dan tidak (Bird, Staines-Orozco, \& Moraros, 2016)ada sangsi moral yang diberikan.

Teman juga dapat mempengaruhi perilaku merokok (18). Merokok dilakukan agar diterima oleh orang lain dan dapat menyesuaikan diri dengan komunitas yang baru. Di antara perokok, terdapat 87\% diantaranya mempunyai satu atau lebih sahabat yang merokok(Leventhal \& Cleary, 1980). Teman tersebut akan menularkan kebiasan merokok kepada teman yang lain dengan cara menceritakan tentang kenikmatan merokok atau sebagai wujud dari solidaritas kelompok. Dari teman sebaya ini kemudian mereka yang belum merokok menginterpretasi bahwa dengan merokok dia akan mendapatkan kenyamanan, dan atau dapat diterima oleh kelompok, dari hasil interpretasi tersebut kemungkinan remaja membentuk dan memperkokoh anticipatory belief, yaitu belief yang mendasari bahwa remaja membutuhkan pengakuan teman sebaya (19). Oleh karena itu, merokok menjadi trend dalam 
pergaulan remaja (Mayzufli, 2013). Mereka takut kalau tidak ikut merokok maka akan dikucilkan oleh teman-temnnya (20).

Hasil penelitian ini menunjukkan bahwa iklan memberikan pengaruh yang tinggi untuk merokok. Hal ini sesuai dengan penelitian dari Lubis pada tahun 2019 yang menunjukkan bahwa sebanyak $98,2 \%$ responden yang merokok pernah terpapar dengan iklan rokok. Responden menyatakan bahwa iklan rokok dapat mendorong seseorang untuk merokok. Hasil penelitian ini sejalan dengan survei yang dilakukan oleh Global Adult Tobacco Survey tahun 2011 yang menyatakan sebanyak 86,4\% responden pernah melihat iklan rokok, sponsor atau promosi (21). Melihat iklan rokok di media massa maupun media elektronik yang menampilkan gambaran bahwa perilaku merokok merupakan lambang kejantanan sehingga menyebabkan remaja mempunyai keinginan untuk meniru apa yang disajikan pada iklan tersebut. Responden mengetahui produk rokok terbaru dari iklan rokok (22).

Penelitian dari Oktaviani pada tahun 2018 pada mahasiswa pria di Universitas Pakuan Bogor juga menyatakan hal yang sama. Penelitian ini menyebutkan bahwa perilaku merokok dipengaruhi oleh iklan. Iklan yang ada pada media massa atau media elektronik menampilkan bahwa merokok adalah lambang kejantanan sehingga membuat orang lain untuk mengikuti perilaku merokok tersebut (23).

\section{KESIMPULAN}

Mayoritas responden pada penelitian ini mulai merokok pertama kali pada usia 17-19 tahun ketika masih SMA. Responden termasuk dalam kategori perokok ringan dan mendapatkan pengaruh sedang dari keluarga serta teman.Perilaku merokok banyak disebabkan oleh pengaruh iklan.Oleh karena itu keluarga sebaiknya tidak mengajari atau memberikan rokok kepada anaknya dan remaja dapat lebih selektif dalam memilih teman.

\section{DAFTAR PUSTAKA}

1. Fikriyah S, Febrijanto Y. Faktor-faktor yang Mempengaruhi Perilaku Merokok Pada Mahasiswa Laki-Laki Di Asrama Putra. 2012;5(1):11.

2. Aula LE. Stop Merokok. Yogyakarta: Garai Ilmu; 2010.

3. Setiyanto d. Perilaku Merokok di Kalangan Pelajar ( Studi Kasus Tentang Faktor dan Dampak dari Perilaku Merokok pada Kalangan Pelajar SMA Negeri 2 Karanganyar). SOSIALITAS; Jurnal Ilmiah Pend Sos Ant [Internet]. 2013 [cited 2019 Nov 7];3(2). Available from: http://jurnal.fkip.uns.ac.id/index.php/sosant/article/view/2645

4. Isfandari S, Lolong D. Analisa Faktor Risiko Dan Status Kesehatan Remaja Indonesia Pada Dekade Mendatang. 2014 [cited 2019 Nov 7];42(2). Available from: http://ejournal.litbang.depkes.go.id/index.php/BPK/article/view/3560

5. Kementerian Kesehatan RI. InfoDATIN Pusat Data dan Informasi Kementerian Kesehatan RI - Perilaku Merokok Masyarakat Indonesia Berdasarkan RISKESDAS 2007 dan 2013. 2013. 
6. Balitbangkes Menkes RI. Riset Kesehatan dasar (RISKESDAS) 2010. Kemenkes RI; 2010.

7. Balitbangkes Menkes RI. Riset Kesehatan dasar (RISKESDAS) 2013. Kemenkes RI; 2013.

8. WHO. report on the global tobacco epidemic 2011 [Internet]. 2011 [cited 2019 Nov 7]. Available from: https://www.who.int/tobacco/global_report/2011/en/

9. Fuadah M. Gambaran Faktor-Faktor Yang Mempengaruhi Perilaku Merokok Pada Mahasiswa Laki-Laki Fakultas Teknik Universitas Negeri Jakarta Angkatan 2009. 2009;75.

10. Subanada IB. Tumbuh kembang Remaja dan Permasalahannya. Jakarta: Sagung Seto; 2008.

11. Mahasiswa FPK. Perilaku Merokok Mahasiswa. 2019.

12. Global Youth Tobacco Survey (GYTS). Fact Sheet: Indonesia [Internet]. 2014. Available from: http://www.search. who.int/tobacco/documents/i no_gyts_report_2014

13. Pertiwi E yeyen, Widati S. Action Situation Perilaku Merokok Di Kawasan Tanpa Rokok Fakultas Kesehatan Masyarakatuniversitas Airlangga. Jurnal Keperawatan Muhammadiyah. 2019;

14. IAKMI. .Buku Bunga Rampai-Fakta Tembakau dan Permasalahannya Edisi V. Jakarta: Tobacco Control and Support Center-IAKMI; 2014.

15. Astuti NH, Barinda S, Hidayat TS, Wathan FM, Liana D. Smoking Behavior among Male Adolescent on Private Junior High Schools in Depok. ARKESMAS. 2018;3(2):12.

16. Hamzah ZM. Faktor-Faktor Yang Melatarbelakangi Remaja Laki-Laki Menjadi Perokok Di Desa Majatengah Kecamatan Kalibening Kabupaten Banjarnegara [Internet] [other]. Faculty of Public Health; 2003 [cited 2019 Nov 7]. Available from: http://www.fkm.undip.ac.id

17. Al-Zalabani A, Kasim K. Prevalence and predictors of adolescents' cigarette smoking in Madinah, Saudi Arabia: a school-based cross-sectional study. BMC Public Health. 2015;15:17.

18. Bird Y, Staines-Orozco H, Moraros J. Adolescents' smoking experiences, family structure, parental smoking and socio-economic status in Ciudad Juárez, Mexico. Int J Equity Health [Internet]. 2016 Feb 20 [cited 2019 Nov 7];15. Available from: https://www.ncbi.nlm.nih.gov/pmc/articles/PMC4761169/

19. Leventhal H, Cleary PD. The smoking problem: A review of the research and theory in behavioral risk modification. Psychological Bulletin. 1980;88(2):370405. 
20. Chung SS, Joung KH. Risk Factors for Smoking Behaviors Among Adolescents. The Journal of School Nursing. 2014 Aug 1;30(4):262-71.

21. World Health Organization. Global adult tobacco survey: Indonesia report 2011. 2012.

22. Tarupay A. Perilaku Merokok Mahasiswi Di Kota Makassar. [Makassar]: Universitas Hasanudin; 2014.

23. Oktaviani N. Faktor-Faktor Yang Berhubungan Dengan Perilaku Merokok Pada Mahasiswa Pria Di Universitas Pakuan Bogor provinsi Jawa Barat Tahun 2018. Promotor Jurnal Mahasiswa Kesehatan Masyarakat [Internet]. 2019 [cited 2019 Nov 7];2(1). Available from: http://ejournal.uikabogor.ac.id/index.php/PROMOTOR/article/view/1788 